\title{
Embedding research into health services in Latin America and the Caribbean: experiences and challenges of the Technical Support Center*
}

\author{
Víctor Becerril-Montekio', Pilar Torres-Pereda ${ }^{1}$, Luis Alberto García-Bello, ${ }^{1}$ and Jacqueline \\ Alcalde-Rabanal ${ }^{1}$
}

Suggested citation Becerril-Montekio V, Torres-Pereda P, García-Bello LA, Alcalde-Rabanal J. Embedding research into health services in Latin America and the Caribbean: experiences and challenges of the Technical Support Center. Rev Panam Salud Publica. 2021;45:e41. https://doi.org/10.26633/RPSP.2021.41

ABSTRACT This article describes the main models for embedding research and the successful experiences and challenges
faced in joint work by researchers and decisionmakers who participated in the Embedding Research for the
Sustainable Development Goals (ER-SDG) initiative, and the experience of the Technical Support Center. In
June 2018, funding was granted to 13 pre-selected research projects from 11 middle- and low-income coun-
tries in Latin America and the Caribbean (Argentina, Bolivia, Brazil, Colombia, Dominican Republic, Ecuador,
Guatemala, Guyana, Haiti, Paraguay, and Peru). The projects focused on the system-, policy-, or program-
level changes required to improve health and build on the joint work of researchers and decisionmakers, with
a view to bringing together evidence production and decision-making in health systems and services. The
Technical Support Center supported and guided the production of quality results useful for decision-making.
This experience confirmed the value of initiatives such as ER-SDG in consolidating bridges between research
on the implementation of health policies, programs, and systems, and the officials responsible for operating
health-related programs, services, and interventions. It highlighted the importance of both respecting and
taking advantage of each context-and the specific arrangements and patterns in the relationships between
researchers and decisionmakers-through incentives for embedded research.

Among efforts to bring the production of validated scientific results closer to decision-making in health systems and services, the initiative for Improving Program Implementation through Embedded Research (iPIER) stands out (1). This initiative, sponsored jointly by the Pan American Health Organization (PAHO) and the Alliance for Health Policy and Systems Research (AHPSR), had two iterations: one in 2014 and one in 2016.

Stemming from the call by the World Health Organization (WHO) for "embedding research into health services" (2),

\footnotetext{
* Official English translation from the original Spanish manuscript made by the Pan American Health Organization. In case of discrepancy, the original version shall prevail. Access to original manuscript: https://doi.org/10.26633/ RPSP.2021.19
}

this initiative encouraged implementers of health programs and policies in Latin America and the Caribbean to design and lead relevant, high-quality scientific research. In addition to improving implementation and operation of health interventions, services, and programs, it sought to bring research closer to decision-making, and at the same time, to overcome considerable challenges around how to achieve this-aspects that require consideration.

The iPIER initiative was designed to promote implementation research embedded into services by combining the capacities,

\footnotetext{
Centro de Investigación en Sistemas de Salud, Instituto Nacional de Salud Pública, Cuernavaca, Morelos, Mexico. $\square$ Pilar Torres-Pereda, pilar.torres@insp.mx
} 
experience, and contextual knowledge of the health workers that run the programs, and the theoretical knowledge and practical experience of researchers. The teams selected to participate included the decisionmaker responsible for a policy, a program, or certain health services-who takes the role of lead or principal researcher-and full-time researchers belonging to the same health institution, an academic institution linked to it, or a civilsociety association with experience in health research.

In 2018, there was a similar initiative: Embedding Research for the Sustainable Development Goals (ER-SDG), sponsored by PAHO, AHPSR, and the WHO Special Program for Research and Training in Tropical Diseases (TDR/WHO) (3). This initiative began with an open call inviting decisionmakers from low- and middle-income countries in Latin America and the Caribbean to submit research proposals focused on needed changes at the system, policy, or program level to improve health. As in the case of the iPIER initiative, the initial approach here was to place the decisionmaker or implementer in the position of principal researcher and head of the research project.

Given the innovative nature of embedding implementation research into health services (4-8), the Technical Support Center, made up of researchers with proven experience, was created to provide technical support. Among its goals were to ensure understanding of the objectives and methodology of implementation research, contribute to better use of findings, advise on drafting recommendations based on scientifically verified data, and support the preparation of materials-such as executive summaries and policy briefs-that help to support decision-making. The ER-SDG initiative is expected to strengthen the process of embedding research into health services, programs, and policies, which would promote discussion and collaboration among researchers and health workers. The premise of the initiative is that all implementation is based on full respect for the particular make-up of each team, autonomy, and the leadership of those in charge of each project.

This article, whose authors were part of the Technical Support Center, describes the main embeddedness models, success stories, and challenges in the joint efforts of researchers and decisionmakers participating in the ER-SDG.

In April and May 2018, over 200 research proposals were received in the form of concept notes. These were thoroughly vetted by the sponsoring institutions using the following criteria: a) a clear goal, articulated in terms of how to improve or correct failures in a health program, system, or policy, through program, systems, and policy research; b) demonstrated evidence of effective engagement to support informed decision-making based on scientifically validated results; c) supporting and preparing institution(s) to ensure successful implementation of the project; d) demonstration of a strong technical understanding of the proposed subject matter; e) capacity to conduct health policy and systems research; and f) willingness to use the results in improving the policies, systems, and programs (3).

In June 2018, PAHO, AHPSR, and TDR/WHO selected and granted financing to 13 teams from 11 low- and middle-income countries in Latin America and the Caribbean where the following languages are spoken: French (Haiti), English (Guyana), Portuguese (Brazil), and Spanish (Argentina, Bolivia, Colombia, Dominican Republic, Ecuador, Guatemala, Paraguay, and Peru). Colombia and Guatemala each had two participating teams. Despite the diversity of languages and cultures in the participating countries, their socioeconomic and sociopolitical realities were similar. Nonetheless, the different problems they were addressing obliged them to make an additional effort to take advantage of both the similarities and differences among work teams and contexts. The teams exhibited differing degrees of research experience, new or long-standing relationships between decisionmakers and researchers, and types of institutional organization that were more or less favorable to embedding research into health services. In such dissimilar conditions, they had to find the best adaptation to discover the flaws in implementation strategies, existing barriers in the health system, and useful conclusions to sustain the best decision-making and propose reasonable and feasible improvements.

The Technical Support Center supported and guided the development of quality findings that were useful for decisionmaking, through the following actions: an in-person workshop on research protocol development and an in-person workshop on data analysis and knowledge translation; periodic monitoring meetings and calls; synchronous and asynchronous virtual seminars; formal interviews; and monitoring logs. Throughout the process and at the end, the Center read and analyzed specific results from each team's research in order to guide and support them in implementation research embedded in services that would meet the highest standards of scientific quality.

Several modalities or basic patterns were found in the relationships between decisionmakers and researchers. These started with the concept of embedding research in health services, in the sense of direct participation by decisionmakers and health workers in the research process itself (7). In the 13 participating teams, several modalities, patterns, and degrees of embeddedness were observed, which meant that the Technical Support Center team had to respectfully adapt to each situation and context in order to help them achieve the greatest benefit in terms of improvements in their health system.

The embeddedness patterns were expressed in the types of relationships developed between the implementers of health programs or services and the researchers to propose, carry out, and successfully complete the research project they submitted as part of the ER-SDG initiative. In all cases, the composition of the selected teams was respected, and the Technical Support Center team's activity was recognized and adapted to three general modalities or patterns of collaboration between decisionmakers and researchers: a) essentially formal, b) mutual learning, and c) consolidation of collaboration.

Essentially formal relationships. In some of the proposals for embedded implementation research in health services, the team of researchers predominated-generally affiliated with academic institutions, with clear theoretical knowledge and practical experience- and the decisionmakers placed their full confidence in the researchers' judgment. In general, the research staff defined, designed, and carried out the research proposal with logistical, administrative, and institutional accompaniment and support from the health services' decisionmakers. In this way, the researchers' knowledge, experience, and professionalism ensured the quality of the research, while mutual trust facilitated utilization of the research findings. This form of collaboration proved to be successful and yielded research findings of high scientific quality, serving as the basis for the preparation of recommendations, executive summaries, and technical reports on health policies. However, it should be recognized that the main limitation of this type of collaboration is its lack of direct impact on developing the research capabilities 
of decisionmakers or on embedding research in services; and while its efforts may be directed at writing scientific articles, it does not necessarily produce the desired improvements in a program. In other words, this type of relationship does not encourage health workers to expand their capacity to produce scientifically validated results and to perceive themselves as direct co-authors and co-owners of the research findings. The involvement of the Technical Support Center-as well as the relationships between local decisionmakers and researchers-remained at a level of formal cordiality that facilitated satisfactory exchanges of good quality outputs. However, this model did not significantly strengthen the research capabilities of the actors directly involved in health services and programs.

Mutual learning relationships. Here, the initial relationship between the two teams is similar to the previous case: decisionmakers and researchers trust each other and there is clear agreement to work collaboratively. Nevertheless, the involvement of decisionmakers is more active and direct, both in the development and implementation of the research protocol and in the analysis of the findings. Sometimes this was the result of decisionmakers having more research experience; sometimes it was supported by or combined with greater willingness on the part of researchers to encourage the direct involvement of decisionmakers in the research process. In this way, the decisionmakers became coparticipants in a mutual learning process, in which they strengthened their analytical skills while contributing their knowledge of the field. The foundations of trust were strengthened, and health workers benefited from their direct proximity to the research process and better understood the nature and scope of the outputs produced, while those who normally researched from outside the services, gained a closer view of field operations. In these cases, the involvement of the Technical Support Center had a positive influence as a facilitator of the relationship between researchers and decisionmakers, by fostering communication through calls, email, and webinars. At the end of the research process, both parties shared ownership of the findings, which not only facilitates their use, but also strengthens implementation research in general as a source of scientifically validated findings that support decision-making and create opportunities for using different kinds of scientific findings in decision-making processes.

This approach is undoubtedly the ideal framework for the ER-SDG initiative, it strengthened the research capabilities of people within the health system at the same time as producing reliable data that meet the system's needs. Nevertheless, there is a risk that the bias of the people who carry out the interventions could tilt the balance toward the merits of their programs more than their shortcomings. In this regard, the presence of a neutral actor-the position occupied by the Technical Support Center-offers a valuable interface that enables the actors to adopt more objective positions.

Consolidation of collaborative relationships. In these cases, decisionmakers within the health system and those who routinely conducted research tended to have a strong history of collaboration. When appropriate institutional arrangements are in place, researchers may already work within health institutions. Even when they are affiliated with academic institutions, they may have developed collaborative ties thanks to previous research. Initiatives such as ER-SDG offer ideal conditions to consolidate this collaboration by ensuring an opportunity for funding, learning, and action to improve decision-making.
Learning the methodology of implementation research embedded in services, which was new for both parties, strengthened both the preexisting horizontality in the collaborative relationship and shared ownership of research findings. As in the previous model, the activities organized by the Technical Support Center facilitated contact and communication among the actors involved in producing those findings.

In cases where relationships are longstanding, failures are often due to previously established power relations. Here too, the presence of an independent actor-such as the Technical Support Center-can be helpful by offering a neutral and scientifically rigorous perspective. In conclusion-and despite the fact that not all elements were considered in this commentary due to space constraints-, the experience gained by the Technical Support Center in the three embeddedness models confirms that initiatives such as ER-SDG are valuable in consolidating bridges between two worlds: that of research on implementation of health policies, programs, and systems, and that of the officials responsible for operating these health programs, services, and interventions. In particular, this experience reveals the importance of providing the necessary accompaniment, support, and guidance to ensure both the scientific quality of the research findings and the feasibility of applying them to improve program implementation. At the same time, this experience highlighted the need to respect and take advantage of each context, as well as specific arrangements and patterns in the relationships among those who work on both sides, by creating incentives to bring them together and strengthen the use of research findings in decision-making. This will undoubtedly result in improved health systems performance.

Encouraging health workers to participate in appropriately rigorous scientific research in order to guide decision-making is an effort that should continue, in order to strengthen the Region's health systems on their road toward universal health coverage and attainment of the Sustainable Development Goals.

Authors' contributions. VBM, PTP, and JAR conceived the original study; VBM and PTP wrote the manuscript; and LAGB collected and analyzed the data. All the authors reviewed and approved the final version of the manuscript.

Acknowledegments. The authors would like to thank PAHO, AHPSR, and TDR/WHO for their support in the establishment and work of the Technical Support Center, especially Ludovic Reveiz and Vanessa Elías, of PAHO; Étienne V. Langlois, of AHPSR; and Freddy Pérez, of TDR/WHO, for their constant support of the participating teams. We thank the participants of the 13 research teams for their generosity in sharing their experiences.

\section{Conflicts of interest. None declared.}

Financial support. Financial support from PAHO (SCON 2018-00415). The sponsors were not involved in any way in the design of the study, data collection and analysis, the decision to publish this paper, or preparation of the manuscript.

Disclaimer. Authors hold sole responsibility for the views expressed in the manuscript, which does not necessarily reflect the opinion or policy of the RPSP/PAJPH or the Pan American Health Organization (PAHO). 


\section{REFERENCES}

1. Pan American Health Organization. The iPIER program in the Americas [Internet]. Washington, DC: PAHO; 2016 [consulted 16 September 2020]. Available at: https://www.paho.org/hq/index .php?option $=$ com_content\&view $=$ article\&id $=11604$ :improving-pro gram-implementation-through-embedded-research-ipier-pro gram\&Itemid $=41011 \&$ lang $=$ en

2. World Health Organization. Changing mindsets - Strategy on health policy and systems research. Geneva: WHO; 2012.

3. Pan American Health Organization. Convocatoria: Embedded Implementation Research for the Sustainable Development Goals (SDG) [Internet]. Washington, DC: PAHO; 2018 [consulted 16 September 2020]. Available at: https://www.paho.org/journal /en/special-issues/embedded-implementation-research-sustain able-development-goals

4. Churruca K, Ludlow K, Taylor N, Long JC, Best S, Braithwaite J. The time has come: Embedded implementation research for health care improvement. J Eval Clin Pract. 2019;25(3):373-80. doi: 10.1111 / jep.13100

5. Langlois EV, Tran NT, Ghaffar A, Reveiz L, Becerra-Posada F. Embedding research in health policy and systems in the Americas. Rev Panam Salud Publica. 2017;41:e68.
6. Peters D, Tran NT. Implementation research in health. A practical guide [Internet]. Geneva: World Health Organization; 2013 [consulted 16 September 2020]. Available at: http://r4d .dfid.gov.uk/pdf/outputs/HealthPolicy/implementationguide _eng.pdf

7. Rasanthan K, Tran NT, Johnson H, Hafeez A, Peterson S, Ghaffar

8. Realizing the potential of embedded implementation research: Lessons from Pakistan. J Glob Health. 2020;10(2):1-3.

9. Tran N, Langlois EV, Reveiz L, Varallyay I, Elias V, Mancuso A, et al. Embedding research to improve program implementation in Latin America and the Caribbean. Rev Panam Salud Publica. 2017;41:e75.

Manuscript (original in Spanish) received on 27 october 2020. Revised version accepted for publication on 31 December 2020.

\section{Experiencias y retos del Centro de Apoyo Técnico en la investigación integrada en los servicios en América Latina y el Caribe}

RESUMEN En este artículo se describen los principales modelos de integración, las experiencias de éxito y los retos del trabajo conjunto de los investigadores y los tomadores de decisiones participantes en la iniciativa Incorporación de la Investigación para Avanzar en el Cumplimiento de los Objetivos de Desarrollo Sostenible (ER-SDG), y la experiencia del Centro de Apoyo Técnico (CAT). En junio de 2018 se otorgó financiamiento, previa selección, a 13 proyectos de investigación de 11 países de ingresos medios y bajos de América Latina y el Caribe (Argentina, Bolivia, Brasil, Colombia, Ecuador, Guatemala, Guyana, Haití, Paraguay, Perú y República Dominicana). Los proyectos debían estar centrados en los cambios que se requieren a nivel de sistema, políticas o programas para mejorar la salud y basarse en el trabajo conjunto de investigadores y tomadores de decisiones, a fin de acercar la generación de evidencias a la toma de decisiones en los sistemas y servicios de salud. El CAT apoyó y orientó la producción de resultados de calidad y de utilidad para la toma de decisiones. La experiencia confirmó el valor de iniciativas como ER-SDG en la consolidación de puentes entre el mundo de la investigación sobre implementación de políticas, programas y sistemas de salud, y el mundo de los funcionarios encargados de operar esos programas, servicios e intervenciones relacionadas con la salud. Se resalta la necesidad de respetar y aprovechar cada contexto, y los arreglos y patrones específicos de relación entre investigadores y tomadores de decisiones, mediante incentivos para la integración.

Palabras clave Ciencia de la implementación; política informada por la evidencia; investigación sobre servicios de salud; América Latina; Región del Caribe. 


\section{Experiências e desafios do Centro de Apoio Técnico na pesquisa integrada aos serviços na América Latina e Caribe}

RESUMO Neste artigo são descritos os principais modelos de integração, as experiências de êxito e os desafios do trabalho conjunto de pesquisadores e responsáveis por tomar decisões que participam da iniciativa Incorporação da Pesquisa para Avançar no Cumprimento dos Objetivos de Desenvolvimento Sustentável (Embedding Research for the Sustainable Development Goals, ER-SDG) e da experiência do Centro de Apoio Técnico (CAT). Em junho de 2018, realizou-se a concessão de financiamento e pré-seleção de 13 projetos de pesquisa provenientes de 11 países de baixa e média renda da América Latina e Caribe (Argentina, Bolívia, Brasil, Colômbia, Equador, Guatemala, Guiana, Haiti, Paraguai, Peru e República Dominicana). Os projetos deveriam enfocar as mudanças necessárias no sistema, políticas ou programas para melhorar a saúde e fundar-se no trabalho conjunto de pesquisadores e responsáveis por tomar decisões visando aproximar a produção de evidências à tomada de decisão nos sistemas e serviços de saúde. O CAT forneceu suporte e orientação à produção de resultados úteis e de qualidade para a tomada de decisão. A experiência confirmou o valor de iniciativas como a ER-SDG para consolidar pontes entre o mundo da pesquisa voltada à implementação de políticas, programas e sistemas de saúde e o mundo dos encarregados de gerir estes programas, serviços e intervenções de saúde. Deve-se enfatizar a necessidade de respeitar e aproveitar cada contexto e os arranjos e padrões próprios da relação entre pesquisadores e responsáveis por tomar decisões criando incentivos à integração.

Palavras-chave Ciência da implementação; política informada por evidências; pesquisa sobre serviços de saúde; América Latina; Região do Caribe. 